\title{
Från tolkad interaktion till enspråkig text - om en asylberättelses framväxt
}

\author{
Cecilia Wadensjö, Hanna Sofia Rehnberg \& Zoe Nikolaidou
}

\section{Inledning}

Vid en asylsökandes första möte med Migrationsverket genomförs ett kortare så kallat ansökningssamtal. I detta medverkar den sökande, en handläggare och en tolk. I nästa steg blir den sökande kallad till ett längre utredande samtal, som i denna artikel benämns asylintervju. Migrationsverkets syfte med asylintervjun, som kan sägas vara kärnan i den asylutredning som myndigheten gör, är att ta fram underlag för att kunna avgöra om den sökande har rätt till asyl i Sverige och i så fall på vilka grunder. Centrala faser i asylintervjun är "den fria berättelsens fas", då den sökande i idealfallet berättar fritt om sina asylskäl, och "sonderingsfasen", då handläggaren ställer frågor till den sökande om asylskälen (se EASO 2014). Närvarar gör, utöver den sökande och Migrationsverkets handläggare, en tolk och vanligen även ett offentligt biträde, som företräder den sökande. Asylintervjun dokumenteras genom att handläggaren fortlöpande skriver på en dator, alltså parallellt med att intervjun pågår. Därefter ges den asylsökande möjlighet att komma med tillägg och korrigeringar. Vanligen görs detta genom att intervjuprotokollet skickas till det offentliga biträdet, som förväntas ombesörja att den sökande får möjlighet att gå igenom det. Biträdet skriver sedan en inlaga till Migrationsverket med argumentation för varför den sökande bör få asyl i Sverige. Därefter fattar Migrationsverket beslut i ärendet. Formellt görs detta av en beslutsfattare, men i praktiken fattas beslutet i samråd med den handläggare som hållit $\mathrm{i}$ asylintervjun. Beslutsunderlaget utgörs av protokollet samt av andra uppgifter som Migrationsverket har tillgång till, exempelvis landinformation.

Även om asylintervjun är en specifik verksamhetstyp, något som framhävs i studier av asylintervjuer, t.ex. av Linell och Keselman (2011) och Barsky (1994, 2016), har den vissa likheter med polisförhör. En likhet av intresse här är att den som leder en intervju samtidigt för protokoll. Att asylintervjuer protokollförs under tiden som de pågår påverkar tolkens arbete på ett konkret sätt, genom att tolken ges och tar ansvar för att tolka för protokollet, konstaterar Pöchhacker och Kolb (2009) i sin närstudie av ljudinspelade asylintervjuer, med engelsktalande sökande, dokumenterade i Österrike. Det faktum att tolkarna i dessa intervjuer uppfattade att de behövde tolka för protokollet innebar två saker som forskarna, med bakgrund inom tolkning och översättning, fann anmärkningsvärt: dels fick de därigenom ett tungt ansvar för den juridiskt relevanta dokumentationen, dels innebar uppgiften en högre kognitiv belastning än vad som hade varit fallet om de enbart hade behövt 
vara inriktade på att återge yttranden på ett annat språk. Att tolka för protokollet innebar, enligt författarna, att tolkarna anpassade utpräglat talspråk på engelska till tysk skriftspråksstandard, asylsökandes svar till på förhand antecknade frågor och berättartempot till skrivarens tempo. Det innebar även att tolkarna dikterade skiljetecken och stavningen på namn och termer som den sökande nämnde, samt att tolkarna repeterade passager som skrivaren ville höra igen (Pöchhacker och Kolb 2009:133). Liknande fynd har gjorts av Pöllabauer (2005:271-273), som även hon studerat tolkade engelsk-tyska asylintervjuer inspelade i Österrike.

I den studie som ligger till grund för denna artikel kan vi se liknande och även andra konsekvenser av att protokollet utgör en part i intervjun som deltagarna behöver förhålla sig till. I denna artikel ligger fokus dock inte på att undersöka kognitiva aspekter av tolkars arbete, utan på hur, mer precist, det kan gå till när en asylberättelse konstrueras och hur det parallella protokollförandet kan påverka asylintervjuns innehåll och progression. Studien har som övergripande mål att öka förståelsen för språkliga och tolktekniska utmaningar, bland Migrationsverkets handläggare, offentliga biträden, tolkar och andra som berörs av asylintervjuer.

\section{Material}

Det material som föreliggande studie bygger på är insamlat inom ramen för ett större projekt, Asylberättelser - om samkonstruktion och rekontextualisering. ${ }^{1}$ Med samkonstruktion avses i detta projekt det faktum att alla de som deltar i asylintervjuer - asylsökande, handläggare, offentliga biträden och tolkar - bidrar till att konstruera den berättelse som talas fram parallellt med att den dokumenteras i skrift. Det större projektet undersöker olika aspekter av berättande i asylprocessen. I denna artikel undersöks hur faktauppgifter med potentiell relevans för ett specifikt asylärende tar skriftlig form i ett protokoll skrivet på svenska, under en intervju genomförd på svenska och ryska. Studien har prövats och godkänts av etisk nämnd och samtliga deltagare har medgivit att vi som forskare kan ta del av ärendets olika delar.

I det ärende som vi diskuterar här har vi tillgång till ett rikt material av ljudinspelningar och dokument. I föreliggande studie utnyttjar vi dock enbart vår ljudinspelning och det skrivna protokollet från den första längre, utredande intervjun ( 2 timmar och 25 minuter) samt det offentliga biträdets inlaga med kommentarer till detta protokoll. Huvudsakligen gör vi en näranalys av en 3 minuter och 25 sekunder lång intervjusekvens.

Den inspelade asylintervjun transkriberades först $\mathrm{i}$ sin helhet, både det svenska och det ryska talet, av medlemmar i forskargruppen. Alla egennamn och andra uppgifter som skulle kunna avslöja enskildas identitet ändrades.

1 Tack till Östersjöstiftelsen för finansiellt stöd och till två anonyma granskare för värdefulla synpunkter på en tidigare version av denna artikel. 
Den asylsökandes första språk är ett annat än ryska men han har godkänt att intervjun genomförs på det språket. Han förstår även lite svenska. Den som tolkar har både tolkutbildning och lång erfarenhet som tolk. Under intervjun sitter handläggaren och den asylsökande tillsammans med det offentliga biträdet, tolken och forskaren runt ett bord. På bordet finns forskarens bandspelare och en dator. Datorns skärm och texten som växer fram är synlig enbart för handläggaren. Där utdraget börjar har intervjun pågått i en kvart.

Genom att utgå från den obegripliga meningen - som den asylsökande och hans offentliga biträde senare ville stryka från protokollet - och jämföra med den ordväxling som fångats via ljudinspelningen, går det att blottlägga, vilka språkliga och pragmatiska omständigheter som tillsammans har skapat förutsättningarna för att en sådan mening alls hamnade där. Dessutom visar den studerade sekvensen på en komplexitet i tolkade asylintervjuer som är svår att få fatt på utan att göra detaljerade analyser av det slag som vi redovisar här, en komplexitet som är viktig för berörda parter att känna till.

\section{Kommunikation i tolkmedierade asylintervjuer}

Denna artikel utgår från ett dialogiskt synsätt på språk och tänkande (jfr Linell 2009). För analyserna har samtalsanalytisk teori och metod tillämpats (se t.ex. Heritage 2005; Schegloff 2007). Med hjälp av mikroanalyser av transkriberade sekvenser hämtade från ljudinspelningen av en autentisk asylintervju har vi kunnat följa hur deltagare svarar på varandras kommunikativa handlingar allt eftersom intervjun fortgår. Till skillnad mot enspråkiga samtal, där närhetspar, som exempelvis fråga-svar, typiskt kommer i en följd, skapas $\mathrm{i}$ tolkade samtal en fördröjning: fråga - återgiven fråga - svar - återgivet svar. Som interaktionistiskt anlagda studier av tolkmedierad diskurs (t.ex. Wadensjö 1998; 2018) har visat, kompliceras det enspråkiga samtalets enklare mönster bland annat just av den nödvändiga fördröjningen mellan fråga och svar i tolkade samtal. Mönstret blir även mer komplext av att kopplingen mellan yttranden på olika språk inte är genomskinlig för de enspråkiga deltagarna. Den komplexitet i organisationen av turtagning och talsekvenser som kommer sig av det samtidiga protokollskrivandet i tolkmedierade asylintervjuer har dock inte undersökts närmare i tidigare forskning. Några finska studier utgör viktiga undantag (Määttä 2015; Määttä et al. 2021).

Hur en asylutredning fungerar är beroende av tolkens språkliga och tolktekniska kompetenser och även av hur deltagarna anpassar sin talproduktion till det tolkade samtalets specifika villkor. Tolkar förväntas hålla sig till god tolksed som den formuleras av den myndighet som auktoriserar tolkar i Sverige, nämligen Kammarkollegiet (2019). I korthet förväntas tolkar tolka allt som sägs, tolka de andras tal i jag-form, förhålla sig opartiska till parterna, inte ge uttryck för egna åsikter och bevara all information konfidentiell. I det här aktuella fallet ser vi hur innehållet $i$ en asylberättelse dock kan grumlas trots att tolken är lojal med dessa principer. 
En omständighet som kan påverka hur asylberättelser formas är när deltagare formulerar sig vagt, något som exempelvis Lee (2009) har uppmärksammat $i$ en studie om tolkning i domstolsförhandlingar. En annan är fragmenteringen som följer av att återgivningar och original måste avlösa varandra ganska tätt i asylintervjuer, något som Tipton (2008) menar gör att asylsökande kan tendera att tappa tråden i den berättelse som de förväntas leverera. En tredje är kopplad till fenomenet reparation (Schegloff, 2007:100-6), inte minst självreparation, det vill säga att en talare avbryter ett yttrande och omformulerar sig. När så sker återger tolkar ofta bara själva omformuleringen och inte det som talaren förkastat. Det kan ske både omedvetet och medvetet. Tolkar kan till exempel vilja undvika att skapa genans eller tvetydighet genom att återge reparerat tal. Den andra parten får då inte vetskap om att en självreparation har skett. Tolkar kan även ha egna behov av att självreparera en formulering på det nya språket. Den som lyssnar kan dock inte veta om detta behov har sitt ursprung hos tolken eller om tolken återger den andres (själv)reparation, såvida inte tolken lyckas förmedla vad som är fallet, exempelvis med hjälp av prosodi (Wadensjö 2018:63, 66-67).

\section{Tre och en halv minuters tal}

I det offentliga biträdets skriftliga inlaga till det protokoll som fördes under den asylintervju som här undersöks finns följande kommentar:

Sida 6, stycke 10 - "Jag hetsar folkgrupper mot varandra medan uigurerna och kineserna är en regering". Sökanden känner inte igen denna mening varpå den ska strykas.

Den citerade meningen återfinns i protokollet, i ett svar på en fråga från handläggaren. Den asylsökande hade tidigare under intervjun berättat att han inte har något pass att visa upp eftersom polisen i hemlandet tagit det ifrån honom för att förhindra honom att resa ut ur landet. I protokollet återges hans svar som ett långt yttrande.

Kan du berätta vad som hände. När tog de passet?

S: det såhär jag berättat att de ringt och kommit men det blir så när de hämtade mig att jag måste kunna samla mig med mina tankar. Då blir så den 20 november kom polisen till mig. Det blev så att polisen kom till mig och började göra rannsakan efteråt anklagade de mig för extremismen. Så och anklagade mig att jag hetsar folkgrupper mot varandra mellan uigurerna kineserna. Jag hetsar folkgrupper mot varandra medan uigurerna och kineserna är en regering.

T: tolken försökte få fram vilken region svaret blev den 20 november

(Ur protokollet från den första längre utredande intervjun, sida 6, stycke 10) 
I det protokoll vi tagit del av inleds flertalet stycken med en bokstav följt av kolon. S står för den sökande och $\mathrm{T}$ står för tolken. Handläggarens frågor skrivs genomgående utan en inledande bokstav.

Det korta replikskiftet från protokollet ovan motsvarades i verkligheten av en sekvens som alltså varade cirka tre och en halv minut och innebar långt fler än tre turväxlingar mellan talarna. I återstoden av detta avsnitt analyseras den aktuella sekvensen bit för bit. Den återges nedan i nio utdrag. I alla utdrag har det som yttrades på ryska försetts med en idiomatisk översättning till svenska som syns i kursiv stil under den ryska texten. Flera kolon i rad efter en vokal (e:::) betyder att vokalen är utdragen i talet. Punkt inom parentes (.) står för en hörbar mikropaus i talflödet. Kommatecken står för fortsättningsintonation, punkt för avslutningsintonation. Ett ohörbart ord markeras med (xx).

Utdrag 1 inleds med att handläggaren formulerar en dubbel fråga: hon ber först om en berättelse, sedan om en tidsangivelse och därefter, med ett utdraget "å::" (rad 1 nedan), antyds igen att det är just en berättelse om ett bestämt tillfälle, inte bara en uppgift om när den ägde rum, som efterfrågas.

\section{Utdrag 1}

Rad 1 Handlägg.: kan du berätta vad som hände? när kom dom å tog passet å::

Rad 2 Tolk: $\quad$ расскажите об обстоятельствах когда они отбирали у вас паспорт и так далее.

berätta om omständigheterna när de tog/när tog de passet från dig och så vidare.

Rad 3 Sökande: они у меня собрали паспорт это вот е::::: я а::: я же рассказывал о том что они приезжали о том что звонили е:: a:: потом приезжали и::: потом в третий раз (.) нет, нет это получается нет а:: то есть а: нет получается короче вот после того как они все приехали, dom tog passet från mig de e så e::. jag jag jag a::: jag berättade ju om att dom kom flera gånger om at dom ringde e:: å::: sen kom dom flera gånger å:: sen den tredje gången (.) nä, nä de e blir så nä me::n alltså å: nä de blir så, kort sagt alltså efter att de hade kommit,

Rad 4 Tolk: de e såhär jag har berättat att dom har ringt å har kommit å sånt. men de blir så, de blir så, de blir så, när dom hämtade mej,

Strax innan den händelse som avspeglas i utdrag 1 har den sökande berättat om tillfället då han blivit fråntagen sitt pass av poliser som kom hem till honom. Genom att be den sökande att berätta detta igen riskerar handläggaren att få honom att framstå som otydlig och sig själv som ouppmärksam. I det aktuella exemplet betonar inte handläggaren "när" i sin fråga ( $\operatorname{rad} 1)$, så tolken får ingen tydlig indikation på ifall tidsangivelsen är viktig eller inte. 
Att formulera sig vagt är en vanlig strategi att ta till för den som vill dämpa en potentiell effekt av ett ansiktshotande uttalande. För studier av enspråkiga samtal myntade Goffman (1967) begreppet face-work. I tolkmedierade samtal, där det som sägs på det andra språket inte är omedelbart transparent för de enspråkiga parterna, är parternas face-work avhängigt av om de förväntar sig att tolken tar på sig att släta över eventuellt ansiktshotande yttranden eller inte och om tolken tar som sin uppgift att täcka upp för parterna om de uttalar sig på ett sätt som motparten kan uppfatta som stötande (jfr Wadensjö 1998; Jacobsen 2010; Lee 2011). Som nämndes ovan förväntar sig Migrationsverket att tolkar verksamma i asylintervjuer ska efterleva god tolksed enligt Kammarkollegiet (2019), vilket innebär att de inte ska släta över eventuellt ansiktshotande uttalanden utan återge dem, något som kräver betydande uppmärksamhet, koncentration och ett visst mod från tolkens sida, och även från den som ställer frågor.

Här återger tolken handläggarens fråga snabbt och entonigt, vilket gör att den låter lika vag på ryska som på svenska. Prosodin hade annars kunnat ange vad ordföljden inte gör på ryska. Två tolkningar av tolkens återgivning blir därför möjliga - "när de tog" (en fråga om vad som hände) och "när tog de" (en fråga om när) ( $\operatorname{rad} 2)$. Även den asylsökandes påföljande svar är vagt. Vagheten kommer sig här snarast av att talaren har svårt att hitta ord. Det ska senare visa sig att den asylsökande har förstått frågan som en fråga om ett specifikt datum.

Den sökande börjar sitt svar ( $\operatorname{rad} 3)$ med att erinra sig själv och lyssnaren om vad han redan sagt om omständigheterna kring att han blev av med sitt pass. Genast stakar han sig och upprepar turuppehållande ord, polučaetsja ("det blir så/det slumpar sig så"), koroče (kortare/kort sagt) och förlängda vokaler, vars främsta uppgift är att markera att talaren söker ord och vill behålla turen, samt markeringar som net a:: to est' ("nä mee::n alltså"), som pekar på att talaren vill självreparera, det vill säga förkasta den första delen av sitt yttrande och formulera sig på nytt. Diskurs av det här slaget är extremt svår att återge för en tolk. Dels är den svår att memorera, dels riskerar tolken att genera talaren om hon försöker härma dennes talsvårigheter (jfr Wadensjö 2018:104 ff). I detta fall antydde tolken den asylsökandes formuleringssvårigheter i sin återgivning genom att upprepa "det blir så" tre gånger i en följd $(\operatorname{rad} 4)$. Eftersom tolken gjorde detta utan att själv låta tveksam måste det ha varit svårt för en person som inte har iakttagit hur intervjupersonen stakat sig, utan enbart lyssnat till den svenska versionen av vad han sagt, att förstå att tolkens upprepning här avspeglar den asylsökandes formuleringsproblem. Att den asylsökande har stora problem med att formulera sig antyds dock av ordväxlingen som följer. 
Utdrag 2

Rad 5 Sökande: ещё собраться я не могу сейчас också samla mig jag har svårt nu

Rad 6 Tolk: jag måste kunna samla mig också, mina tankar.

(.)

Rad 7 Sökande: е::: получается полиция а::: они приехали ко мне 20 ноября, e:: det blir så polisen a $::$ dom kom till mig den 20 november,

Rad 8 Tolk: de blir så den 20 november polisen kommer hem ti- kom till mej. ursäkta.

Den asylsökande kommenterar nu sin pågående talproduktion och låter därigenom förstå att hans berättelse pausas: "också samla mig jag har svårt nu" (rad 5). Tolken återger detta yttrande innan den sökande tar turen igen och håller kvar den, synbarligen villig att fortsätta svara men inte helt klar över hur han ska fortsätta ( $\operatorname{rad} 7)$. Av detta förs "jag måste kunna samla mig, mina tankar" till protokollet. Tolken upprepar igen "det blir så" (rad 8). En jämförelse mellan rad 7 och rad 8 får det återigen att framstå som troligt att tolken verkligen försöker återge allt som den asylsökande säger, inklusive det turuppehållande polučaetsja ("det blir så/det slumpar sig så") ( $\operatorname{rad} 7)$. Dock härmar hon inte hans långa tvekpauser "e::::" och "a::::" $(\operatorname{rad} 7)$. Den sökandes diskurs är full av sådana och att härma dessa skulle naturligtvis kunna uppfattas som extremt ansiktshotande, men det hade möjligen kunnat göra handläggaren mer uppmärksam på den sökandes formuleringsproblem. Samtidigt hade tolken dock riskerat att själv framstå som den som har problem med att formulera sig. Beroende på kontexten behöver tolkar avväga i vilken mån de kan "visa fram" eller "spela upp" vad parterna säger. ${ }^{2}$

Slutligen reparerar tolken något som hon själv just sagt - "kommer hem ti- kom till mig" ( $\operatorname{rad} 8)$ - när hon upptäcker att hon använt fel tempus. Det avslutande "ursäkta" ( $\operatorname{rad} 8)$ markerar tolken som sitt eget tillägg genom att skifta tonhöjd och röstvolym, och det är inget som hamnar i protokollet. Det gör däremot en hel del av det som den sökande säger som snarast är ämnat att kommentera och reparera det egna talet, alltså inte att fylla på med innehåll i asylberättelsen.

När intervjun fortsätter är den asylsökandes talproduktion fortsatt trevande.

2 För en diskussion om dessa olika tolkstrategier, kallade relaying by displaying respektive relaying by replaying, se Wadensjö 1998:246-248. 
Utdrag 3

Rad 9 Sökande: и:: полиция они получается, ко мне домой пришли, и::: ачали всё обыскивать дома.

å:: polisen dom det blir så, kom in hos mig $i$ mitt hem, å::

började leta runt överallt hos mig.

Rad 10 Tolk: det blev så att polisen kom hem till mig, å dom började (.) göra sin rannsakan,

Den sökande nämner igen att polisen kommit hem till honom, och när tolken återger vad han sagt använder hon det juridiskt färgade ordet "rannsakan" (rad 10), dock inte husrannsakan, den juridiskt korrekta termen för en polisiär husundersökning. Tolken hade kunnat välja ett mer vardagligt ord, som "leta" (rad 9). Men det ryska substantivet obysk (sök/husrannsakan) och verbet obyskivat' (söka/leta) har samma rot. I tolkens snabba val av stilnivå hamnar hon på den högre. Intressant nog kan den sägas vara mer anpassad till handläggarens och det offentliga biträdets referensramar än till talarens/den asylsökandes dito. Att tolkar anpassar återgivningar till lyssnares förväntningar i valet mellan möjliga tolkningar är begripligt och inte alls ovanligt, eftersom tolken på så sätt bäddar säkrare för lyssnarens bidrag till fortsatt dialog. I protokollet syns tolkens ordval - "rannsakan" - och inget annat.

För att inte riskera att glömma detaljer $\mathrm{i}$ ett yttrande kan tolkar ibland tendera att ta turen och flika in en återgivning, om än aldrig så kort, så snart tillfälle ges. Å ena sidan kan deltagare uppfatta detta som något som förstärker samtalets fragmentariska karaktär. $\AA$ andra sidan, för en berättare som förväntar sig återkoppling, kan tolkningen på det andra språket fungera som en slags bekräftelse, som uppmuntrar till fortsatt tal. I detta samtal förekommer ofta, som i utdraget nedan, att den sökande går ner i prosodi, något som brukar signalera att en tanke är avslutad, och därefter yttrar en konjunktion i form av en utdragen vokal "å:::" ( $\operatorname{rad} 11)$, något som vanligen signalerar att talaren har mer att säga. Den utdragna vokalen tycks trigga tolkens snabba återgivning.

Utdrag 4

Rad 11 Sökande:и после этого они меня о::обвинили в экстремизме. [и::: якобы och efter detta a::anklagade de mig för extremism. [å::: de påstår

Rad 12 Tolk: [efteråt dom anklagade mej i extremismen.

För tolken kan det vara svårt att avgöra om en snabbt inflikad återgivning är motiverad. Å ena sidan säkrar den möjligheten för den aktuella lyssnaren att följa vad som sagts samtidigt som den bekräftar för den aktuella talaren att tolken följer denne uppmärksamt. Å andra sidan, att avvakta med återgivningen kan motiveras av att den skulle kunna störa talarens tankegång (jfr Tipton 2008). Efter turväxlingen i rad 11-12 fortsätter dock den sökande sin 
påbörjade tanke (rad 13 nedan) och handläggaren kan protokollföra det som den sökande sagt, både om att han anklagats för extremism och om vad som skulle ha motiverat denna anklagelse.

\section{Utdrag 5}

Rad 13 Sökande: якобы я вызываю е:: н- н- национальную рознь м:: (.) якобы я вызываю национальную рознь мм между уйгурами и китайцами.

det påstås att jag framkallar e:: e-e-etnisk fientlighet m:: (.) det påstås att jag framkallar etnisk fientlighet me me me mellan uigurer och kineser

Rad 14 Tolk: $\quad$ så och anklagade dom mej attt jag hetsar folkgrupperna mot varandra, att jag hetsar folkgrupper mot varandra mellan uigurerna och, между уйгурами и? mellan uigurer och?

Rad 15 Sökande: и китайцами [этими

Rad 16 Tolk: [och kineserna

Tolkars yttranden fyller två grundläggande funktioner, dels som återgivningar av andras tal på ett nytt språk, dels som samordnande kuggar i en pågående diskurs. Återgivningar fungerar implicit samordnande i kraft av att de, i princip, kommer som varannan tur i ett tolkat samtal. Vissa av tolkars yttranden fungerar explicit samordnande. Till exempel kan tolkar behöva försäkra sig om att de har hört rätt. ${ }^{3}$ Här gör tolken detta genom att med frågeintonation repetera något den sökande nyss sagt på ryska: "mellan uigurer och?" (rad 14). Det får avsedd effekt. Den sökande fyller i med "och kineser" ( $\operatorname{rad} 15)$, som tolken återger ( $\operatorname{rad} 16)$. Av det överlappade "dessa" ( $\operatorname{rad} 15)$ och fortsättningen ( $r a d 17$ nedan) förstår vi att den sökande var i färd med att precisera att hans sak inte gällde vilka kineser som helst utan de kineser som bor i Xinjiangregionen. 
Utdrag 6

Rad 17 Sökande: и этими китайцами которые живут в этом Синьцзяне, в автономном районе

å dessa kineser som bor där $i$ Xinjiang, $i$ den autonoma regionen.

Rad 18 Tolk: $\quad$ ме- то есть между уйгурами и китайцами? правильно? я говорю.

me- alltså mellan uigurer och kineser? är det korrekt? som jag säger?

$\operatorname{Rad} 19$ Sökande: да. между уйгурами и китайцами, якобы я выставлял, ja. mellan uigurerna och kineserna, det påstås att jag har lagt ut,

Möjligen missar tolken regionens namn eftersom hon fortsatt är upptagen av att försäkra sig om att hon hört rätt (rad 18) innan hon uppdaterar handläggaren. Den sökande bekräftar korrektheten i "mellan uigurerna och kineserna" ( rad 19) och gör därefter en ny ansats till att nämna vad han har anklagats för. Det framgår av tolkens nästa yttrande att hon har anklagelsen klar för sig och att hon har hört honom nämna en region men inte uppfattat vilken ( $\operatorname{rad} 20$, nedan). Egennamn, särskilt om de är obekanta för lyssnaren, är en känd utmaning för tolkar, vilket illustreras av sekvensen som följer.

Utdrag 7

\begin{tabular}{|c|c|}
\hline Rad 20 Tolk: & $\begin{array}{l}\text { да понятно. [в каком районе? } \\
\text { det är klart. [i vilken region?/ungefär när? }\end{array}$ \\
\hline Rad 21 Sökande: & $\begin{array}{ll}{[(\mathrm{xx})} & \text { (.) } \mathrm{a} ? \\
{[(x x)} & \text { (.) } v a ?\end{array}$ \\
\hline
\end{tabular}

Rad 22 Tolk: $\quad$ в каком районе вы сказали?

$i$ vilken region/ungefär när sa ni?

Rad 23 Sökande: это было 20 ноября..

det var den 20 november.

Tolken ber igen om en repetition av något den sökande sagt ( $\operatorname{rad} 20$ och 22). Den sökande hör eller förstår först inte (rad 21) och svarar sedan på ett sätt som kan ge intryck av att han här har tappat tråden ( $\operatorname{rad} 23)$. Men så behöver det faktiskt inte ha varit. Om den sökande tror att tolken har hört att han nämnt Xinjiang (rad 17) och nu är inriktad på att svara på utredarens fråga "när?" kan han ha uppfattat $v$ kakom rajone? ("i vilken region?/ungefär när?") på ett sätt som tolken inte verkar ha förväntat sig, nämligen som "ungefär när". Den asylsökandes snabba svar ( $\operatorname{rad} 23)$ vittnar om att han är angelägen om att visa att han kan ange ett exakt datum. Det faktum att frågan $v$ kakom rajone? kan uppfattas på olika sätt skapar ett brott i den aktuella asylberättelsen som knappast någon hade kunnat förvänta sig, ett brott som alltså gav avtryck $\mathrm{i}$ protokollet.

Tolken avvaktar en kort stund innan hon fortsätter. 
Utdrag 8

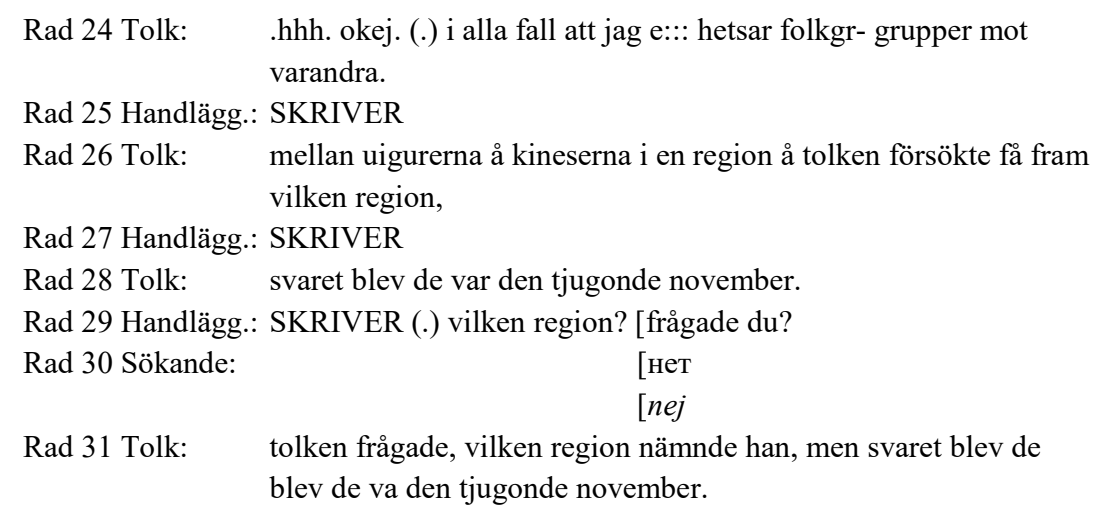

Efter mikropausen följer en tung utandning, ett "okej" ( $\operatorname{rad} 24)$, som signalerar tolkens ansats till att börja tala, en ny mikropaus och sedan "i alla fall" (rad 24), i sammanhanget snarast att förstå som en reservation för att det som ska följa kan te sig underligt. Något som bidrar till att lyssnaren kan uppfatta det så är att tolken här inte upprepar någon svensk motsvarighet till den ryska partikeln jakoby, ett uttryck som återkommande används av den sökande (t.ex. rad 19). Denna partikel, som markerar att man anför någon annans påstående, kan översättas på flera olika sätt på svenska beroende på kontexten, till exempel med det påstås, de säger eller som i tolkens tidigare återgivningar: "dom anklagade mej" ( $\operatorname{rad} 12$, rad 14). Men här, när tolken återger den asylsökandes yttrande igen (utdrag 8), sker det utan markeringen att det som sägs om honom är vad någon annan har påstått. Handläggaren kopplar inte heller "att jag e::: hetsar folkgr- grupper mot varandra" (rad 24) till det som tolken sagt innan, utan denna formulering förs in i protokollet som ett konstaterande av ett faktum.

I utdrag 8 ovan framgår tydligt hur tolken orienterar sig mot det pågående protokollskrivandet. Hon matar på med information allt eftersom tangentbordet tystnar. Hon återger den sökandes yttranden som hon har uppfattat dem och hon återger också sin egen kontrollfråga till honom. Hon tydliggör att det är "tolken" ( $\operatorname{rad} 26)$ som initierat kontrollfrågan, allt enligt gängse normer för tolkning i offentlig sektor. Den aktuella tolken är utan tvivel skolad i tolkteknik och tolketik. Ändå sås i denna sekvens ett frö till ett missförstånd som blir protokollfört och inte närmare utrett. Vi vet inte om handläggaren hör den protest som kommer från den sökande i form av ett net ("nej") (rad 30). Vi vet inte heller om handläggaren tänker att namnet på den region som tolken försökt få fram alls är av vikt. Av fortsättningen förstår vi att handläggaren är tillbaka vid den inledande fråga som återgavs i rad 1, och nu, dryga tre minuter senare, formuleras den tydligare ( $\operatorname{rad} 32$ nedan). På inspelningen hörs den som en inbjudan till den sökande att berätta fritt om hur det gick till när hans pass blev beslagtaget, snarare än en fråga om att ange en bestämd tidpunkt. 
Utdrag 9

Rad 32 Handlägg.: okej. kan du berätta om när dom tog ditt pass?

Rad 33 Tolk: когда собрали? när? när tog dom/dom tog?

Rad 34 Handlägg.: mm,

Rad 35 Sökande: ну::: в тот момент они всё собрали получается паспорт ja::: vid det tillfället tog dom allt det blir så passet.

Rad 36 Tolk: de blev exakt e:h vid den stunden som de tog passet. med sig.

Rad 37 Handlägg.: SKRIVER okej.

Oturligt nog behöver tolken kontrollera också handläggarens fråga ( $\operatorname{rad} 32)$. Kontrollfrågan kommer först på ryska, vilket tyder på att tolken ställt in sig på att adressera den sökande, men repeteras genast på svenska: "när?" (rad 33). Själva växlingen mellan arbetsspråken är en av de större utmaningarna vid tolkning i samtal. Att ord på "fel" språk smyger sig in i talet är vanligt hos tvåspråkiga (Skaaden 2017:83) och händer ibland även rutinerade tolkar. Fortsättningen tyder på att både handläggaren och den sökande uppfattat sig som tilltalad. Tolkens korta yttrande följs av handläggarens återkoppling "mm," (rad 34), som lätt kan förstås som en bekräftelse på att något uppfattats korrekt och som inbjuder till att fortsätta. Den sökande kan ha uppfattat denna signal. I alla händelser blir det han som fortsätter. Han inväntar alltså inte en ny återgivning från tolken utan verkar ha uppfattat hennes kontrollfråga kogda sobrali? ("när tog dom/dom tog?") (rad 33) som en återgivning av handläggarens fråga ( $\operatorname{rad} 32)$ och formulerar ett svar ( $\operatorname{rad} 35)$. Även om detta svar innehåller få, om ens någon detalj om hur det gick till när den sökande blev av med sitt pass, så nöjer sig handläggaren med detta, säger "okej” ( $\operatorname{rad} 37)$ och återkommer inte till denna fråga igen.

\section{Sammanfattande diskussion}

Det tal som i protokollet sammanfattades i tre repliker - en fråga från handläggaren, ett svar från den sökande (eller snarare en svensk version av ett ryskspråkigt svar) och en kommentar till detta svar från tolken - motsvarades i verkligheten av dryga tre minuters tal, uppdelat på 37 talturer som särskilt mot slutet interfolierades med samtidigt protokollskrivande. I analysen av talturerna synliggörs ett flertal omständigheter som påverkar framväxten av asylberättelsen. Den första är vaghet, i såväl handläggarens fråga som i den sökandes tal. Vaga formuleringar kan ha sin grund i olika kommunikativa fenomen, allt ifrån en talares önskan att inte genera sin samtalspartner till en talares formuleringsproblem. I det aktuella fallet (utdrag 1) tillkommer dessutom en vaghet som hänger ihop med asylintervjuns två centrala faser - den fria berättelsens fas och sonderingsfasen. Handläggaren har i början av intervjun sagt att hon först vill låta den asylsökande berätta fritt om sina asylskäl och att hon därefter kommer att ställa frågor. Förstod tolken och sedan den asylsökande hennes fråga ( $\mathrm{rad} 1)$ som en inbjudan till fortsatt fritt 
berättande, eller som en fråga som syftar till att klargöra en tidpunkt, eller både och? Gränsen mellan asylintervjuns fas ett och två, som handläggaren har annonserat ska komma, kan ha tett sig oklar för den sökande, av flera skäl. Transkriptionen av den aktuella intervjun visar också att den tänkta fasindelningen inte motsvarar den faktiska. Utdrag 1 visar en vagt formulerad inbjudan att berätta fritt. Handläggarens nästa inbjudan är inte vag ( $\operatorname{rad} 32)$, men tolken hinner inte återge den innan den sökande behandlat den som en riktad fråga, och den sökandes riktade svar följs inte upp. Handläggaren går vidare till en ny fråga.

Utdrag 2 illustrerar att tolken, som verkar inriktad på att tolka allt som sägs, tolkar både det som den sökande säger för att lägga till innehåll till asylberättelsen och det som han säger för att administrera själva berättandet. För den som skriver protokollet kan det vara svårt att avgöra vad som är vad. I det aktuella fallet, där den asylsökande genomgående har problem med att hitta ord, ofta stammar och gör självreparationer, blir denna fråga genomgående aktuell i de två asylintervjuer med honom som vi observerat.

Ibland måste tolkar sekundsnabbt välja mellan olika möjliga översättningar av ett ord eller uttryck. Detta illustreras här första gången i utdrag 3 , där tolkens val för att återge den sökandes obyskivat' står mellan ett vardagligare uttryck för att söka eller leta igenom en bostad och ett juridiskt uttryck för polisiär husundersökning. Ett annat exempel är frågan $v$ kakom rajone? (i vilken region?/ungefär när?) (utdrag $7, \operatorname{rad} 22$ ). Ords potentiella mångtydighet snarare ökar än minskar när två språk är inblandade och deltagarna ser olika kontexter som givna. Det faktum att olika saker kan åsyftas med ett och samma ord eller uttryck är utbildade tolkar ofta beredda på. Till exempel ställer tolken senare i samma intervju en snabb kontrollfråga för att klargöra om den asylsökande med babusjka åsyftar 'farmor' eller 'mormor'. Ett och samma ord på ryska motsvaras av två olika på svenska. I exemplet som återges i utdrag 7 har tolken hört den sökande säga rajon ('region') och hon är uppenbarligen inte beredd på att ordet tillsammans med v kakom ('i vilken') kan förstås metaforiskt.

Utdrag 4 och 5 belyser hur turtagningen i tolkade samtal styrs av tolkens avvägning när det gäller om hon ska utnyttja mikropauser för att leverera tolkning av korta sekvenser, eller avvakta tills den som talar tydligt lämnar ifrån sig ordet. Skälen för att utnyttja en mikropaus är 1) att den andra primära parten, det vill säga lyssnaren, hålls uppdaterad, 2) att en återgivning kan fungera som en positiv återkoppling till talaren och 3) att risken för att tolken ska glömma någon detalj minimeras. Skäl emot kan vara att talaren riskerar att tappa tråden och därför producerar fragment snarare än en sammanhängande berättelse, som Tipton (2008) har påpekat. I den aktuella sekvensen ser vi även en annan nackdel, nämligen att tolken med en kontrollfråga riskerar att tappa fokus från den pågående diskursen, vilket kan göra att hon missar potentiellt viktiga detaljer. 
Utdrag 6 visar att ett geografiskt namn, Xinjiang, och det faktum att tolken inte uppfattar det direkt blir källa till ett missförstånd. Detta missförstånd kom sedan att avspegla sig i protokollet (sid 6) i formuleringen: "tolken försökte få fram vilken region svaret blev den 20 november". För handläggaren, och för den beslutsfattare som läser protokollet, kan tolkens kommentar uppfattas som att den sökande varit ovillig att lämna en uppgift.

Att protokollet blir en part i samtalet som turtagningen måste anpassas efter demonstreras i utdrag 8 och 9. Tolken reglerar tydligt sin egen turtagning med hänsyn till protokollskrivandet. Ett sådant fokus kan leda till att yttranden som kommer parallellt med det tal som designas för protokollet bortprioriteras, vilket här hände med den sökandes protest $(\operatorname{rad} 30)$.

I ljuset av denna undersökning ter sig de obegripliga raderna i protokollet som den asylsökande inte kände igen ("Jag hetsar folkgrupper mot varandra medan uigurerna och kineserna är en regering".) snarast som en preliminär formulering, en skrivrest, som handläggaren missat att ta bort. Att samtidigt skriva protokoll och leda en intervju kan utan tvekan utmana en handläggares uppmärksamhet och förmåga.

I denna artikel har vi visat hur mångtydighet $\mathrm{i}$ språk och komplexitet $\mathrm{i}$ turtagning påverkar vad som hamnar i protokollet från en asylintervju. Generellt för tolkade samtal gäller att gränsen mellan mina och dina ord kan framstå som suddig: de primära parterna kan ha svårt att avgöra vems tveksamhet, oro eller tvärsäkerhet som färgar ett yttrande, den andra partens eller tolkens, i synnerhet om deltagarna inte iakttar varandra under samtalet utan är upptagna av annat, som här, där en deltagare samtidigt skriver protokoll. I ett tolkat samtal, där minst tre meningsskapande individer deltar, varav två inte talar samma språk, ökar dessutom komplexiteten i hur deltagarna skapar mening av det som sägs och görs.

Undersökningen av ordväxlingen, de tre och en halv minuters tal som resulterade i den korta protokolltext som återgavs i början av denna analys, visar att tre deltagare i asylintervjun bidragit till innehållet - den asylsökande genom att berätta och kommentera sitt berättande, handläggaren genom att ställa frågor och överföra tal till skrift och tolken genom sina ordval och sitt sätt att flika in återgivningar. Samtliga dessa deltagare har dessutom bidragit genom sitt sätt att anpassa sig till den tolkade intervjuns icke-standardmässiga turtagning. Undersökningen visar att ogenomskinligheten i vilka språkliga handlingar som utförs på det andra språket, och vem som utför vilka språkliga handlingar, kan göra det svårt både för handläggaren att föra protokoll och för den asylsökande att lämna bidrag till protokollet. Resultatet pekar mot att deltagarnas kunskaper om turtagning i tolkmedierade samtal och om skillnader mellan talspråk och skriftspråk kan ha betydelse för utformningen av den text som hamnar i protokollet.

Detta resultat manar till närmare studier av fler asylintervjuer, med olika konstellationer av deltagare, språk och kompetensnivåer hos de professionella parterna. Detaljerade undersökningar av det slag som genomförts här skulle 
naturligtvis inte kunna genomföras på plats, av deltagare i en asylintervju. Men utbildning i och kunskap om språkliga och kommunikativa utmaningar i tolkade asylintervjuer skulle enligt vår mening göra handläggare vid migrationsmyndigheter, offentliga biträden och tolkar bättre rustade.

\section{Referenser}

Barsky, Robert F. (1994), Constructing a Productive Other: Discourse theory and the convention refugee hearing. Philadelphia: John Benjamins.

Barsky, Robert F. (2016), Undocumented immigrants in the area of arbitrary law: The flight and plight of people deemed "illegal". Abingdon, UK: Routledge.

EASO (2015), EASO practical guide: Personal interview. (EASO Practical Guide Series, December 2014.) European Asylum Support Office. https://easo. europa.eu/sites/default/files/public/EASO-Practical-Guide-PersonalInterview-EN.pdf [Hämtad 2020-11-28].

Goffman, Erving (1967), Interaction ritual: Essays on face-to-face behavior. New York: Pantheon.

Heritage, John (2005), "Conversation analysis and institutional talk", i Sanders, Robert \& Kristine Fitch (red.), Handbook of Language and Social Interaction, Mawah, NJ, Erlbaum, s. 103-146.

Jacobsen, Bente (2010), "Interactional pragmatics and court interpreting: An analysis of face", i Schlesinger, Miriam \& Franz Pöchhacker (red.), Doing Justice to Court Interpreting [Benjamins Current Topics 26] s. 193-239.

Kammarkollegiet (2019), God tolksed. Kammarkollegiets råd till auktoriserade tolkar.: https://www.kammarkollegiet.se/download/18.27f1fe4c168c1d8 17515205f/1551777027993/God_tolksed_mars2019.pdf [Hämtad 202005-08].

Lee, Jieun (2009), Interpreting inexplicit language during courtroom examination. Applied Linguistics 30(1), s. 93-114.

Lee, Jieun (2011), A study of facework in interpreter-mediated courtroom examination, Perspectives Studies in Translatology 21(1), s. 1-18.

Linell, Per (2009), Rethinking Language, Mind and World Dialogically: Interactional and Contextual Theories of Human Sense-making. Charlotte, NC: Information Age Publishing.

Linell, Per \& Olga Keselman (2011), ’Trustworthiness at stake: Trust and distrust in investigative interviews with Russian adolescent asylum-seekers in Sweden", i Alex Gillespie \& Ivana Marková (red.), Trust and Conflict: Representation, Culture and Dialogue. Hove: Routledge, s. 156-180.

Määttä, Simo (2015), Interpretation the discourse of reporting: The case of screening interviews with asylum seekers and police interviews in Finland. Translating \& Interpreting, 7(3), s. 21-35.

Määttä, Simo, Puumala, Eeva \& Ylikom, Riita (2021), Linguistic, psychological and epistemic vulnerability in asylum prodedures: An interdisciplinary approach, Discourse Studies 23(1), s. 46-66.

Pöchhacker, Franz \& Waltraub Kolb (2009), "Interpreting for the record", i Sandra Hale, Uldis Ozolins \& Ludmila Stern (red.), The Critical Link 5: 
Quality in interpreting - a shared responsibility. Amsterdam: John Benjamins, s. 119-134.

Pöllabauer, Sonja (2005), 'I don't understand your English, Miss". Dolmetschen bei Asylanhörungen. Tübingen: Narr.

Schegloff, Emmanuel (2007), Sequence Organization in Interaction: A Primer in Conversation Analysis. Vol 1. Cambridge: Cambridge University Press.

Skaaden, Hanne (2017), Den tvåpartiska tolken. Nacka: Sköna konster.

Tipton, Rebecca (2008), Reflexivity and the social construction of identity in interpreter-mediated asylum interviews. The Translator 14(1), s. 1-19.

Wadensjö, Cecilia (1998), Interpreting as Interaction. London: Longman.

Wadensjö, Cecilia (2018), Kontakt genom tolk (andra upplagan). Stockholm: Dialogos. 